\title{
Impact of Shading on Wheat Crop in Poplar Based Agroforestry Practice of Northern Plain of Uttar Pradesh, India
}

\author{
Divya $\operatorname{Yadav}^{1 *}$, Charan Singh ${ }^{1}$ and Harikesh Singh ${ }^{2}$ \\ ${ }^{1}$ Extension Division, Forest Research Institute, Dehradun (Uttarakhand), India \\ ${ }^{2}$ Department of Entomology, Gochar Mahavidyalaya Rampur Maniharan, Saharanpur \\ (Uttar Pradesh), India \\ *Corresponding author
}

\section{A B S T R A C T}

\begin{tabular}{|l|}
\hline Ke y w or d s \\
$\begin{array}{l}\text { Populus deltoides, } \\
\text { Wheat, Shading } \\
\text { effect }\end{array}$ \\
\hline Article Info \\
\hline $\begin{array}{l}\text { Accepted: } \\
\text { 26 January } 2018 \\
\text { Available Online: } \\
\text { 10 February } 2018\end{array}$ \\
\hline \hline
\end{tabular}

The present study was conducted in $2014-15$ in five tehsils (Behat, Deoband, Nakur, Rampur Maniharan and Saharanpur) of Saharanpur district which is north-western part of Uttar Pradesh, India to observe the effect of shading of border plantation of poplar (Populus deltoides) on wheat crop. The four parameters (total tillers per plant, ineffective tillers per plant, grain yield and biological yield) were recorded. The total tillers were significantly more in unshaded area, while ineffective tillers were significantly increased in shaded areas of wheat crop in both the years. Grain yield was significantly reduced in all villages of Behat, Nakur, Rampur Maniharan and Saharanpur tehsils, while in Deoband tehsil yield was at par in two villages in shaded and unshaded wheat crop. The maximum reduction in yield due to shading was recorded in Behat tehsils with 48.20 to 49.62 percent. Biological yield (grain+straw) was also significantly reduced in shaded area by border plantation of poplar. Results in 2015 were confirmatory for all parameters as similar trend.

\section{Introduction}

Poplar (Populus deltoides) based agroforestry is being practiced on a large scale in the Northern plain of Uttar Pradesh. The farmer grow poplar because of its short rotation period, ease of regeneration (coppice), leaflessness during winters, soil enriching, easy availability of quality planting material, good economic return with easy marketing and its compatibility with different agricultural crops. Poplar is popularized among the farmers and wheat (Triticum aestivum) is one of the most important rabi crop being grown with association of boundary plantation of poplar (Sharma and Dadhwal, 1996). Jain and Singh (2000) found poplar-based agroforestry economically viable and more profitable than many other crop rotations. Sensitivity analysis indicates that this system is not risky.

Age of poplar ( $P$. deltoides) trees is recorded as the most important factor influencing grain yield of intercropped wheat. On an average, reduction in grain yield was $20.10 \%$ under 1year-old poplar plantation, which increased to $54 \%$ under 4-year-old plantation in Punjab 
(Chauhan et al., 2009). Many studies have shown that shading reduces grain yield (Gill et al., 2009; Mu et al., 2010). Huawei (2010) indicate that the effect on grain yield is dependent on the level of shading applied and that the effect is also cultivar-dependent. Low shading might not reduce or even increase wheat grain yield due to high efficient light capture brought about by the morphological modifications and changes of light fractions. The crop yield is certainly affected by the shade of the trees in tree-crop combinations but the resources use efficiency is better under trees than in open conditions. However, on system basis the productivity of the combination is more than pure cropping (Chauhan et al., 2013). Keeping the above view the experiment was carried out to observe the effect of polar boundary plantation on wheat crop to generate data for agroforestry economics.

\section{Materials and Methods}

The present study was conducted in five tehsils (Behat, Deoband, Nakur, Rampur Maniharan and Saharanpur) of Saharanpur district which is north-western part of Uttar Pradesh. The district lies between $29^{\circ} 34^{\prime}$ to $30^{\circ} 23^{\prime} \mathrm{N}$ and $77^{\circ} 05^{\prime}$ to $77^{\circ} 58^{\prime} \mathrm{E}$ with a geographical area of $3,689 \mathrm{~km}^{2}$. It has an average elevation of 284 meters (above sea mean level). Saharanpur district forms the most northerly position of the Doab land which stretches between the holy rivers of the Ganges and the Yamuna. Topographically, the district can be divided into five parts viz., shiwalik hill tract, bhabar, khaddar, Tarai and plain land (Yamuna, Hindon). Yamuna is the important river of the district. The soil is mainly sandy and sandy loam, which is easily erodible by rain water and causing severe soil erosion. Saharanpur has a tropical and subhumid climate. The annual rainfall ranged from 498 to $1,566 \mathrm{~mm}$ and a temperature range of $6.6^{\circ} \mathrm{C}$ to $45^{\circ} \mathrm{C}$ with the average temperature of $23.3^{\circ} \mathrm{C}$. The total reporting area for land utilization of the district was estimated at 3, 63,791 ha in 2011-12. More than $75 \%$ of the reporting area has been brought under net sown in the district and average landholding size is 1.27 ha (Statistical abstract, U.P., 2013).

Stratified random sampling was adopted to select the agroforestry fields. There were randomly three sample villages selected from each stratum using the random number table and village number assigned in Saharanpur district census, 2011. Total fifteen sample villages were surveyed for the study then five agroforestry farms were randomly selected from each sample villages of each strata using random number table and khasra number. From each farm five quadrates of $1 \times 1 \mathrm{~m}^{2}$ were randomly selected from shaded and unshaded areas of boundary plantations of poplar for crop estimation of wheat.

The study was carried out for two consecutive years i.e. 2014 and 2015 for wheat with boundary plantation of Populus deltoides, respectively. The observations were taken from November 2013 sown wheat which was harvested in April 2014. On the selected farm, the age of poplar tree was four year in 2014 and five years in 2015. The plantation was done in January 2010 at $0.9 \times 0.9 \mathrm{~m}$ spacing in boundary plantation.

The four parameters (total tillers per plant, ineffective tillers per plant, grain yield and biological yield) of yield were recorded to observe the effect of shading of boundary planted poplar in wheat crop. The numbers of tillers and ineffective tillers (i.e. those not bearing spikes) of the ten randomly selected plants were counted at before harvesting in shaded and unshaded areas in each farm and mean was calculated. Sample from shaded areas were taken in east and south direction. The shade was measured at 10 am from east 
and at $2 \mathrm{pm}$ from south side. Total shaded area was divided by five and the distance was measured from the plantation boundary and each quadrat was taken at each $5^{\text {th }}$ distance of total shade to represent the whole shaded area.

Grain yield and biological yield (grain+straw) was observed by harvesting at five quadrats of $1 \mathrm{x} 1 \mathrm{~m}^{2}$ areas in shaded and unshaded areas in each farm and left for two days in the field to dry. Yield in $\mathrm{kg}$ per hectare ( $\mathrm{kg} / \mathrm{ha})$ was calculated. Two sample t-test was used to compare the means of different parameters of shaded and unshaded areas. The percent difference was calculated due to shading by assuming as standard value for each parameter in unshaded areas.

\section{Results and Discussion}

Various parameters were recorded to observe the effect of shading on wheat crop in all five tehsils of Saharanpur district. All parameters showed the different degree of variation under shaded areas. Table 1 revealed that the total numbers of tiller were significantly increased in shaded areas of wheat in Behat tehsil in 2014 crop season. The difference was 12.71 to 17.56 percent while in Nakur tehsil the total tiller were at par in both the conditions. However, in rest three tehsils the total tillers were significantly increased. It ranged from 4.93 to 15.01 percent increase in shaded areas. Similarly in 2015 also the total tillers of wheat increased significantly in Behat tehsil with 15.50 to 21.55 percent increment (Table 2). While in Nakur tehsils, there was no significant difference in total tillers in shaded and unshaded wheat crop. The highest difference was observed in unshaded area of Saharanpur tehsils.

Ineffective tillers were significantly increased in shaded area of wheat crop in both the years (Table 3 and 4). In 2014, the maximum ineffective tiller were observed in Behat tehsils in shaded areas of wheat with range of 141.78 to 152.44 percent more than unshaded areas, while difference was less in Deoband and Saharanpur tehsils. Similar trend was also observed in 2015 in all tehsils. This parameter has more impact on grain yield.

Perusal of table 5 revealed that grain yield was significantly reduced in all villages of Behat, Nakur, Rampur Maniharan and Saharanpur tehsils, while in Deoband tehsils yield was at par in two villages in shaded and unshaded wheat crop.

The maximum reduction in yield due to shading was recorded in Behat tehsils with 48.20 to 49.62 percent lower yield in shaded wheat crop. In rest of the tehsils the grain yield was reduced from 15.30 to 28.32 percent in 2014. In 2015, the grain yield was significantly reduced due to shading in all villages of all five tehsils (Table 6).

The maximum grain yield reduction was 64.14 to 69.28 percent in Behat tehsils, followed by Nakur 39.94 to 41.31 percent, while the lowest reduction in grain yield due to poplar shading was in Rampur Maniharan with 10.42 to 11.61 percent.

The overall reduction in grain yield of wheat was higher due to shading in the year 2015 as compared to 2014. This may be due to more shading effect in 2015 as the border plantation was 5 years old in 2015 and 4 year old in 2014.

Singh and Kumar (2014) have also reported similar finding and observed that the grain yield of wheat crop was maximum under control plots; i.e., $4.55 \mathrm{t} / \mathrm{ha}$, which was higher than the crop grown under boundary plantation (3.28 t/ ha) and lowest at block plantation $(2.03 \mathrm{t} / \mathrm{ha})$. The yield reduction was minimum $(11.05 \%)$ in one year old poplar and maximum $(44.90 \%)$ in five year old poplar. 
Table.1 Difference (\%) in total tillers of wheat per hectare by shading of poplar plantation in tehsils of Saharanpur district in the year 2014

\begin{tabular}{|c|c|c|c|c|c|c|c|}
\hline \multirow[t]{2}{*}{ Tehsil } & \multirow[t]{2}{*}{ Village } & \multicolumn{2}{|c|}{ Total tillers (per hill) } & \multirow[t]{2}{*}{ t-test } & \multirow[t]{2}{*}{$t_{\text {cal }}$} & \multirow[t]{2}{*}{ Difference (\%) } & \multirow{2}{*}{$\begin{array}{l}\text { Tehsil-wise mean } \\
\text { difference }(\%)\end{array}$} \\
\hline & & Shaded & Unshaded & & & & \\
\hline \multirow[t]{3}{*}{ Behat } & Asgarpur Must & 8.69 & 7.71 & $\mathrm{~S}$ & 4.85 & -12.71 & -15.19 \\
\hline & Belka Mafi & 8.65 & 7.50 & S & 5.87 & -15.30 & \\
\hline & Shahpur Garha & 8.46 & 7.20 & S & 6.15 & -17.56 & \\
\hline \multirow[t]{3}{*}{ Deoband } & Kapoori Govindpur & 7.01 & 7.68 & S & 2.77 & 8.75 & 7.86 \\
\hline & Manjhaul Jabardastpur & 6.72 & 7.34 & S & 2.61 & 8.50 & \\
\hline & Miragpur & 6.86 & 7.32 & S & 2.34 & 6.34 & \\
\hline \multirow[t]{3}{*}{ Nakur } & Nalhera & 7.89 & 8.24 & $S$ & 2.11 & 4.25 & 1.93 \\
\hline & Nakur & 8.24 & 8.16 & NS & 0.65 & 0.97 & \\
\hline & Chhapar & 7.88 & 7.92 & NS & 0.33 & 0.58 & \\
\hline \multirow[t]{3}{*}{ Rampur Maniharan } & Bhankla & 6.32 & 7.18 & $\mathrm{~S}$ & 4.84 & 11.75 & 10.56 \\
\hline & Jagrauli & 7.01 & 7.38 & S & 2.15 & 4.93 & \\
\hline & Janderi & 6.34 & 7.46 & S & 4.66 & 15.01 & \\
\hline \multirow[t]{3}{*}{ Saharanpur } & Tiwaya Must & 7.19 & 7.93 & S & 3.78 & 9.33 & 9.07 \\
\hline & Ismailpur & 7.23 & 7.78 & S & 2.87 & 6.99 & \\
\hline & Mazari Khurd & 7.18 & 8.05 & S & 4.87 & 10.88 & \\
\hline
\end{tabular}

*S=Significant at 5\% level, NS=Non significant

Table.2 Difference (\%) in total tillers of wheat per hectare by shading of poplar plantation in different tehsils of Saharanpur district in the year 2015

\begin{tabular}{|c|c|c|c|c|c|c|c|}
\hline \multirow[t]{2}{*}{ Tehsil } & \multirow[t]{2}{*}{ Village } & \multicolumn{2}{|c|}{ Total tillers (per hill) } & \multirow[t]{2}{*}{ t-test } & \multirow[t]{2}{*}{$\mathbf{t}_{\text {cal }}$} & \multirow[t]{2}{*}{ Difference (\%) } & \multirow{2}{*}{$\begin{array}{l}\text { Tehsil-wise mean } \\
\text { difference (\%) }\end{array}$} \\
\hline & & Shaded & Unshaded & & & & \\
\hline \multirow[t]{3}{*}{ Behat } & Asgarpur Must & 8.52 & 7.38 & $\mathrm{~S}$ & 5.13 & -15.50 & -18.68 \\
\hline & Belka Mafi & 8.57 & 7.20 & $\mathrm{~S}$ & 5.72 & -18.99 & \\
\hline & Shahpur Garha & 8.26 & 6.79 & S & 6.30 & -21.55 & \\
\hline \multirow[t]{3}{*}{ Deoband } & Kapoori Govindpur & 6.76 & 7.76 & S & 2.52 & 12.94 & 11.48 \\
\hline & Manjhaul Jabardastpur & 6.39 & 7.21 & S & 2.67 & 11.33 & \\
\hline & Miragpur & 6.51 & 7.25 & S & 3.69 & 10.17 & \\
\hline \multirow[t]{3}{*}{ Nakur } & Nalhera & 7.78 & 8.48 & $\mathrm{~S}$ & 4.04 & 8.32 & 6.20 \\
\hline & Nakur & 8.18 & 8.17 & NS & 0.83 & 7.82 & \\
\hline & Chhapar & 7.74 & 7.94 & NS & 1.38 & 2.46 & \\
\hline \multirow[t]{3}{*}{ Rampur Maniharan } & Bhankla & 6.28 & 6.18 & NS & 0.17 & -0.07 & -5.80 \\
\hline & Jagrauli & 6.93 & 6.11 & $\mathrm{~S}$ & 4.04 & -13.43 & \\
\hline & Janderi & 6.06 & 5.83 & NS & 0.10 & -3.91 & \\
\hline \multirow[t]{3}{*}{ Saharanpur } & Tiwaya Must & 7.02 & 8.13 & $\mathrm{~S}$ & 4.78 & 13.63 & 13.08 \\
\hline & Ismailpur & 7.06 & 7.92 & S & 4.39 & 10.81 & \\
\hline & Mazari Khurd & 7.04 & 8.27 & $\mathrm{~S}$ & 6.15 & 14.80 & \\
\hline
\end{tabular}


Table.3 Difference (\%) in ineffective tillers of wheat per hectare by shading of poplar plantation in tehsils of Saharanpur district in the year 2014

\begin{tabular}{|c|c|c|c|c|c|c|c|}
\hline \multirow[t]{2}{*}{ Tehsil } & \multirow[t]{2}{*}{ Village } & \multicolumn{2}{|c|}{ Ineffective tillers (per hill) } & \multirow[t]{2}{*}{ t-test } & \multirow[t]{2}{*}{$\mathbf{t}_{\text {cal }}$} & \multirow[t]{2}{*}{ Difference (\%) } & \multirow{2}{*}{$\begin{array}{c}\text { Tehsil-wise mean } \\
\text { difference }(\%)\end{array}$} \\
\hline & & Shaded & Unshaded & & & & \\
\hline \multirow[t]{3}{*}{ Behat } & Asgarpur Must & 4.24 & 1.75 & $\mathrm{~S}$ & 19.01 & -141.78 & \multirow{3}{*}{-147.52} \\
\hline & Belka Mafi & 4.19 & 1.69 & S & 20.15 & -148.34 & \\
\hline & Shahpur Garha & 4.14 & 1.64 & S & 17.01 & -152.44 & \\
\hline \multirow[t]{3}{*}{ Deoband } & Kapoori Govindpur & 2.92 & 1.76 & $\mathrm{~S}$ & 6.16 & -66.14 & \multirow[t]{3}{*}{-76.13} \\
\hline & Manjhaul Jabardastpur & 2.78 & 1.77 & S & 5.19 & -57.11 & \\
\hline & Miragpur & 2.88 & 1.40 & S & 9.65 & -105.13 & \\
\hline \multirow[t]{3}{*}{ Nakur } & Nalhera & 3.43 & 1.51 & $S$ & 29.91 & -127.29 & \multirow[t]{3}{*}{-138.01} \\
\hline & Nakur & 3.33 & 1.36 & S & 31.13 & -143.99 & \\
\hline & Chhapar & 3.30 & 1.36 & S & 34.67 & -142.75 & \\
\hline \multirow[t]{3}{*}{ Rampur Maniharan } & Bhankla & 1.96 & 1.07 & S & 7.44 & -83.90 & \multirow[t]{3}{*}{-127.23} \\
\hline & Jagrauli & 2.58 & 0.96 & S & 12.72 & -168.05 & \\
\hline & Janderi & 2.04 & 0.89 & S & 10.80 & -129.73 & \\
\hline \multirow[t]{3}{*}{ Saharanpur } & Tiwaya Must & 2.90 & 1.72 & S & 10.82 & -68.37 & \multirow[t]{3}{*}{-67.91} \\
\hline & Ismailpur & 3.02 & 1.85 & S & 11.97 & -63.28 & \\
\hline & Mazari Khurd & 3.06 & 1.78 & S & 13.74 & -72.07 & \\
\hline
\end{tabular}

$*$ S=Significant at $5 \%$ level

Table.4 Difference (\%) in ineffective tillers of wheat per hectare by shading of poplar plantation in tehsils of Saharanpur district in the year 2015

\begin{tabular}{|c|c|c|c|c|c|c|c|}
\hline \multirow[t]{2}{*}{ Tehsil } & \multirow[t]{2}{*}{ Village } & \multicolumn{2}{|c|}{ Ineffective tillers (per hill) } & \multirow[t]{2}{*}{ t-test } & \multirow[t]{2}{*}{$\mathbf{t}_{\text {cal }}$} & \multirow[t]{2}{*}{ Difference (\%) } & \multirow{2}{*}{$\begin{array}{l}\text { Tehsil-wise mean } \\
\text { difference }(\%)\end{array}$} \\
\hline & & Shaded & Unshaded & & & & \\
\hline \multirow[t]{3}{*}{ Behat } & Asgarpur Must & 4.53 & 2.14 & $\mathrm{~S}$ & 19.38 & -111.59 & \multirow{3}{*}{-118.27} \\
\hline & Belka Mafi & 4.60 & 2.00 & $\mathrm{~S}$ & 20.81 & -130.66 & \\
\hline & Shahpur Garha & 4.34 & 2.04 & $\mathrm{~S}$ & 13.32 & -112.55 & \\
\hline \multirow[t]{3}{*}{ Deoband } & Kapoori Govindpur & 3.17 & 2.69 & NS & 1.98 & -17.83 & \multirow[t]{3}{*}{-42.93} \\
\hline & Manjhaul Jabardastpur & 2.70 & 1.89 & $\mathrm{~S}$ & 4.70 & -42.83 & \\
\hline & Miragpur & 2.84 & 1.69 & S & 6.45 & -68.13 & \\
\hline \multirow[t]{3}{*}{ Nakur } & Nalhera & 3.41 & 1.90 & S & 20.19 & -79.23 & \multirow[t]{3}{*}{-97.96} \\
\hline & Nakur & 3.58 & 1.67 & S & 14.39 & -114.55 & \\
\hline & Chhapar & 3.31 & 1.66 & S & 27.87 & -100.11 & \\
\hline \multirow[t]{3}{*}{ Rampur Maniharan } & Bhankla & 2.06 & 1.30 & S & 4.94 & -58.19 & \multirow[t]{3}{*}{-79.74} \\
\hline & Jagrauli & 2.82 & 1.34 & $\mathrm{~S}$ & 10.66 & -111.08 & \\
\hline & Janderi & 2.15 & 1.26 & S & 7.41 & -69.94 & \\
\hline \multirow[t]{3}{*}{ Saharanpur } & Tiwaya Must & 2.90 & 2.17 & S & 7.09 & -33.42 & \multirow[t]{3}{*}{-32.00} \\
\hline & Ismailpur & 3.04 & 2.27 & $\mathrm{~S}$ & 7.50 & -33.63 & \\
\hline & Mazari Khurd & 3.06 & 2.38 & S & 7.30 & -28.96 & \\
\hline
\end{tabular}

$* \mathrm{~S}=$ Significant at $5 \%$ level, $\mathrm{NS}=$ Non-significant 
Table.5 Difference (\%) in grain yield of wheat per hectare by shading of poplar plantation in tehsils of Saharanpur district in the year 2014

\begin{tabular}{|c|c|c|c|c|c|c|c|}
\hline \multirow[t]{2}{*}{ Tehsil } & \multirow[t]{2}{*}{ Village } & \multicolumn{2}{|c|}{ Grain yield (kg/ha) } & \multirow[t]{2}{*}{ t-test } & \multirow[t]{2}{*}{$t_{\text {eal }}$} & \multirow[t]{2}{*}{ Difference (\%) } & \multirow{2}{*}{$\begin{array}{l}\text { Tehsil-wise mean } \\
\text { difference }\end{array}$} \\
\hline & & Shaded & Unshaded & & & & \\
\hline \multirow[t]{3}{*}{ Behat } & Asgarpur Must & $2,091.60$ & $4,152.00$ & $\mathrm{~S}$ & 11.21 & 49.62 & 49.02 \\
\hline & Belka Mafi & $2,133.20$ & $4,118.40$ & S & 11.12 & 48.20 & \\
\hline & Shahpur Garha & $2,100.40$ & $4,136.80$ & $\mathrm{~S}$ & 11.16 & 49.23 & \\
\hline \multirow[t]{3}{*}{ Deoband } & Kapoori Govindpur & $4,880.00$ & $5,456.00$ & NS & 1.65 & 10.56 & 10.63 \\
\hline & Manjhaul Jabardastpur & $4,864.00$ & $5,478.00$ & NS & 1.75 & 11.21 & \\
\hline & Miragpur & $5,461.60$ & $6,076.40$ & $\mathrm{~S}$ & 12.61 & 10.12 & \\
\hline \multirow[t]{3}{*}{ Nakur } & Nalhera & $4,490.40$ & $6,264.40$ & S & 16.70 & 28.32 & 26.88 \\
\hline & Nakur & $4,767.20$ & $6,378.00$ & S & 15.93 & 25.26 & \\
\hline & Chhapar & $4,704.00$ & $6,448.00$ & S & 16.39 & 27.05 & \\
\hline \multirow[t]{3}{*}{ Rampur Maniharan } & Bhankla & $5,926.80$ & $7,000.00$ & S & 11.42 & 15.33 & 15.59 \\
\hline & Jagrauli & $5,887.20$ & $7,020.40$ & S & 11.10 & 16.14 & \\
\hline & Janderi & $5,916.80$ & $6,985.20$ & $\mathrm{~S}$ & 11.46 & 15.30 & \\
\hline \multirow[t]{3}{*}{ Saharanpur } & Tiwaya Must & $4,206.80$ & $5,568.40$ & S & 6.27 & 24.45 & 24.77 \\
\hline & Ismailpur & $4,172.40$ & $5,594.80$ & S & 6.27 & 25.42 & \\
\hline & Mazari Khurd & $4,585.20$ & $6,068.80$ & S & 8.62 & 24.45 & \\
\hline
\end{tabular}

$* *$ S=Significant at $5 \%$ level, NS=Non significant

Table.6 Difference (\%) in grain yield of wheat per hectare by shading of poplar plantation in tehsils of Saharanpur district in the year 2015

\begin{tabular}{|c|c|c|c|c|c|c|c|}
\hline \multirow[t]{2}{*}{ Tehsil } & \multirow[t]{2}{*}{ Village } & \multicolumn{2}{|c|}{ Grain yield (kg/ha) } & \multirow[t]{2}{*}{ t-test } & \multirow[t]{2}{*}{$\mathbf{t}_{\text {cal }}$} & \multirow[t]{2}{*}{ Difference (\%) } & \multirow{2}{*}{$\begin{array}{l}\text { Tehsil-wise mean } \\
\text { difference }\end{array}$} \\
\hline & & Shaded & Unshaded & & & & \\
\hline \multirow[t]{3}{*}{ Behat } & Asgarpur Must & $1,268.00$ & $3,536.00$ & $\mathrm{~S}$ & 9.93 & 64.14 & 65.88 \\
\hline & Belka Mafi & $1,394.00$ & $4,537.00$ & S & 36.49 & 69.28 & \\
\hline & Shahpur Garha & $1,262.00$ & $3,530.00$ & S & 9.04 & 64.23 & \\
\hline \multirow[t]{3}{*}{ Deoband } & Kapoori Govindpur & $2,222.00$ & $3,656.80$ & S & 9.85 & 39.24 & 39.35 \\
\hline & Manjhaul Jabardastpur & $2,281.20$ & $3,886.40$ & S & 11.68 & 41.30 & \\
\hline & Miragpur & $2,177.20$ & $3,484.00$ & S & 9.16 & 37.51 & \\
\hline \multirow[t]{3}{*}{ Nakur } & Nalhera & $3,325.20$ & $5,665.60$ & S & 35.97 & 41.31 & 40.40 \\
\hline & Nakur & $3,410.00$ & $5,677.20$ & S & 32.31 & 39.94 & \\
\hline & Chhapar & $3,400.00$ & $5,664.00$ & S & 33.35 & 39.96 & \\
\hline \multirow[t]{3}{*}{ Rampur Maniharan } & Bhankla & $5,420.80$ & $6,132.80$ & S & 4.64 & 11.61 & 10.99 \\
\hline & Jagrauli & $5,343.60$ & $6,000.80$ & S & 4.28 & 10.95 & \\
\hline & Janderi & $5,312.00$ & $5,930.00$ & S & 4.06 & 10.42 & \\
\hline \multirow[t]{3}{*}{ Saharanpur } & Tiwaya Must & $2,464.00$ & $3,626.40$ & S & 5.43 & 32.05 & 29.58 \\
\hline & Ismailpur & $2,468.00$ & $3,477.60$ & S & 5.05 & 29.03 & \\
\hline & Mazari Khurd & $2,416.00$ & $3,339.20$ & S & 4.60 & 27.65 & \\
\hline
\end{tabular}


Table.7 Difference (\%) in biological yield of wheat per hectare by shading of poplar plantation in tehsils of Saharanpur district in the year 2014

\begin{tabular}{|c|c|c|c|c|c|c|c|}
\hline \multirow[t]{2}{*}{ Tehsil } & \multirow{2}{*}{ Village } & \multicolumn{2}{|c|}{ Biological yield (kg/ha) } & \multirow[t]{2}{*}{ t-test } & \multirow{2}{*}{$\mathbf{t}_{\text {cal }}$} & \multirow{2}{*}{ Difference (\%) } & \multirow{2}{*}{$\begin{array}{c}\text { Tehsil-wise mean } \\
\text { difference }(\%)\end{array}$} \\
\hline & & Shaded & Unshaded & & & & \\
\hline \multirow[t]{3}{*}{ Behat } & Asgarpur Must & 6,852 & 10,796 & $\mathrm{~S}$ & 8.76 & 36.53 & \multirow[t]{3}{*}{35.33} \\
\hline & Belka Mafi & 6,912 & 10,636 & S & 8.92 & 35.01 & \\
\hline & Shahpur Garha & 6,876 & 10,488 & S & 8.67 & 34.44 & \\
\hline \multirow[t]{3}{*}{ Deoband } & Kapoori Govindpur & 9,544 & 13,452 & S & 5.37 & 29.05 & \multirow[t]{3}{*}{30.35} \\
\hline & Manjhaul Jabardastpur & 9,620 & 13,692 & $S$ & 5.50 & 29.74 & \\
\hline & Miragpur & 10,292 & 15,192 & S & 11.40 & 32.25 & \\
\hline \multirow[t]{3}{*}{ Nakur } & Nalhera & 10,108 & 14,476 & S & 8.85 & 30.17 & \multirow[t]{3}{*}{30.32} \\
\hline & Nakur & 10,772 & 15,168 & S & 8.92 & 28.98 & \\
\hline & Chhapar & 10,636 & 15,532 & S & 9.49 & 31.52 & \\
\hline \multirow[t]{3}{*}{ Rampur Maniharan } & Bhankla & 13,064 & 19,076 & S & 20.18 & 31.52 & \multirow[t]{3}{*}{31.89} \\
\hline & Jagrauli & 12,836 & 19,104 & S & 18.68 & 32.81 & \\
\hline & Janderi & 13,108 & 19,088 & S & 19.66 & 31.33 & \\
\hline \multirow[t]{3}{*}{ Saharanpur } & Tiwaya Must & 9,856 & 12,832 & S & 5.58 & 23.19 & \multirow[t]{3}{*}{24.04} \\
\hline & Ismailpur & 9,888 & 12,956 & S & 5.96 & 23.68 & \\
\hline & Mazari Khurd & 10,576 & 14,148 & S & 6.68 & 25.25 & \\
\hline
\end{tabular}

$* \mathrm{~S}=$ Significant at $5 \%$ level

Table.8 Difference (\%) in biological yield of wheat per hectare by shading of poplar plantation in tehsils of Saharanpur district in the year 2015

\begin{tabular}{|c|c|c|c|c|c|c|c|}
\hline \multirow[t]{2}{*}{ Tehsil } & \multirow[t]{2}{*}{ Village } & \multicolumn{2}{|c|}{ Biological yield (kg/ha) } & \multirow[t]{2}{*}{ t-test } & \multirow[t]{2}{*}{$\mathbf{t}_{\text {cal }}$} & \multirow[t]{2}{*}{ Difference $(\%)$} & \multirow{2}{*}{$\begin{array}{l}\text { Tehsil-wise mean } \\
\text { difference }(\%)\end{array}$} \\
\hline & & Shaded & Unshaded & & & & \\
\hline \multirow[t]{3}{*}{ Behat } & Asgarpur Must & $5,776.80$ & 10,072 & $\mathrm{~S}$ & 8.01 & 42.64 & 40.07 \\
\hline & Belka Mafi & $7,300.00$ & 11,160 & S & 14.57 & 34.59 & \\
\hline & Shahpur Garha & $5,796.00$ & 10,168 & S & 7.22 & 42.99 & \\
\hline \multirow[t]{3}{*}{ Deoband } & Kapoori Govindpur & 5,640 & 8,072 & S & 5.35 & 30.13 & 30.08 \\
\hline & Manjhaul Jabardastpur & 5,924 & 8,240 & S & 4.20 & 28.11 & \\
\hline & Miragpur & 5,536 & 8,140 & S & 5.88 & 31.99 & \\
\hline \multirow[t]{3}{*}{ Nakur } & Nalhera & 8,080 & 14,064 & S & 12.42 & 42.55 & 41.01 \\
\hline & Nakur & 8,216 & 13,644 & S & 13.99 & 39.78 & \\
\hline & Chhapar & 8,080 & 13,628 & S & 14.03 & 40.71 & \\
\hline \multirow[t]{3}{*}{ Rampur Maniharan } & Bhankla & 11,448 & 17,140 & S & 13.37 & 33.21 & 31.16 \\
\hline & Jagrauli & 11,488 & 16,464 & S & 10.75 & 30.22 & \\
\hline & Janderi & 11,332 & 16,200 & S & 10.14 & 30.05 & \\
\hline \multirow[t]{3}{*}{ Saharanpur } & Tiwaya Must & 7580 & 9460 & S & 5.67 & 19.87 & 18.30 \\
\hline & Ismailpur & 7668 & 9324 & S & 5.61 & 17.76 & \\
\hline & Mazari Khurd & 7512 & 9080 & S & 4.96 & 17.27 & \\
\hline
\end{tabular}


Ahmed (1989) was also recorded that in the first two years after plantation, the effect of trees on crop production was almost negligible, in the $3^{\text {rd }}$ and $4^{\text {th }}$ year loss was 8.20 percent, it increased to 13.60 percent in the $5^{\text {th }}$ and $6^{\text {th }}$ year and increased. Poplar offered maximum competition near the tree line (0-3 $\mathrm{m})$ and reduced the grain and straw yield by 10.70 and 16.70 percent, respectively.

Biological yield (grain + straw) was also significantly reduced in shaded area by border plantation of poplar (Table 7 and 8) in both the years. The maximum reduction was recorded in Behat tehsils (34.44 to 36.53 percent), followed by Nakur and Rampur Maniharan tehsils in 2014 (Table 7), while lowest reduction was 23.19 to 25.25 percent in Saharanpur tehsils. Similar trend was also observed in 2015, but the degree of reduction in biological yield was higher than 2014 because of more shading effect (Table 8).

\section{References}

Ahmed, P. 1989. Eucalyptus in agroforestry: its effect on agricultural production and economics. Agroforestry Systems, 8 (1): 331-38.

Chauhan, S. K., Dhillon, W. S., Singh, N., Sharma, R. 2013. Physiological Behaviour and Yield Evaluation of Agronomic Crops Under Agri-hortisilviculture System. International Journal of Plant Research, 3(1): 1-8.

Chauhan, S.K., Nanda, R.K. and Brar, M.S. 2009. Adoption of poplar based agroforestry as an approach for diversified agriculture in Punjab. The Indian Forester, 135(5): 671-677.

Gill, R., Singh, B., Kaur, N., 2009. Productivity and nutrient uptake of newly released wheat varieties at different sowing times under poplar plantation in north-western India. Agroforestry System. 76 (3): 579-590.

Huawei, LI., Jianga, D, Wollenweberb, B., Daia, T. and Weixing, C. 2010. Effects of shading on morphology, physiology and grain yield of winter wheat. European Journal of Agronomy. 33: 267- 275.

Jain, S.K. and Singh, P. 2000. Economics analysis of industrial agroforestry poplar (Populus deltoides) in U.P. (India). Agroforestry Systems, 49 (3): 255-273.

Mu, H., Jiang, D., Wollenweber, B., Dai, T., Jing, Q. and Cao, W. 2010. Long-term low radiation decreases leaf photosynthesis, photochemical efficiency and grain yield in winter wheat. J. Agron. Crop Sci 196: 38-47.

Sharma, N. K. and Dadhwal, K. S. 1996. Prominent agroforestry practices in the Saharanpur plains of Uttar Pradesh - a case study. Indian Journal of Soil Conservation, 24 (2), 172-173.

Singh, A. and Kumar, A. 2014. Criticle issue in Poplar-based agroforestry system. Indian Journal of Agroforestry. 16(1): 58-67.

Statistical Abstract, Uttar Pradesh. 2013. Economics and statistics division, State Planning Institute, U.P., Lucknow.

\section{How to cite this article:}

Divya Yadav, Charan Singh and Harikesh Singh. 2018. Impact of Shading on Wheat Crop in Poplar Based Agroforestry Practice of Northern Plain of Uttar Pradesh, India. Int.J.Curr.Microbiol.App.Sci. 7(02): 2955-2962. doi: https://doi.org/10.20546/ijcmas.2018.702.359 